\title{
Exploring Academic Literacy Practices in Postgraduate Level
}

\author{
Pratiwi Retnaningdyah \\ Universitas Negeri Surabaya \\ Surabaya, Indonesia \\ pratiwiretnaningdyah@unesa.ac.id
}

\author{
Kisyani Laksono \\ Universitas Negeri Surabaya \\ Surabaya, Indonesia
}

\begin{abstract}
Higher education requires that college students across disciplines develop and master academic literacies to succeed academically. Academic literacies constitute reading, writing, speaking, critical thinking, use of technology, and certain habits that foster thinking process, and should be introduced before college entry. This paper examines postgraduate students' academic literacy practices at Universitas Negeri Surabaya (Unesa). The practices include reading, writing, critical habits of mind, and the use of technology in learning process. The data were collected through questionnaires given to 33 postgraduate students of TEFL programme. Interviews regarding academic literacy practices were also conducted with 6 students. The results of the study suggest that students' academic literacies are still unsatisfactory, especially in terms of academic reading comprehension ability, academic writing competence, and critical habits of mind. Similarly, students also perceive that their academic literacy practices have not met the expectations set by their lecturers. These findings give an implication that assistance in academic skills should be provided to promote academic literacy competence in postgraduate programme.
\end{abstract}

Keywords-academic literacies; critical thinking; academic writing; learning outcomes

\section{INTRODUCTION}

In the past ten years, there has an increasing trend among Indonesian people to pursue postgraduate studies. While this trend indicates a positive sign in people's interest in higher education to develop their intellectual mind, the increase does not necessarily mean an increase in academic literacy competence among postgraduate students. Meanwhile, the literacy demands in postgraduate level are certainly different and more complex than those in undergraduate level. For one thing, learner autonomy in producing academic writing is highly expected of postgraduate students. Meanwhile, there is an assumption that postgraduate students have already mastered academic literacy practices required to succeed academically. This assumption is based on the fact that they have already passed the undergraduate level [1]. The academic gap between expectations and realities indicate that there is an urgent need to equip postgraduate students with academic literacy strategies that can support learning processes. The objective of this paper is to examine the postgraduate students' perception of academic literacy practices in three areas: their academic writing competence, their academic reading practices, and the use of technology to support learning process in the English Education Postgraduate program of Universitas Negeri Surabaya, Indonesia.

Academic literacy is frequently understood as a mean to enable learners in higher education to read, interpret, and evaluate texts critically. Academic literacy helps a student to participate effectively in the process of comprehending an academic text and writing an academic essay or assignment. This understanding is related to a common perception that a successful learner is also a good reader [2].

Research trends in literacy in an academic setting reflect a shift in the meaning of literacy as a set of skills to a social practice. This shift in definition of literacy is part of New Literacy Studies. According to Barton, et al. [3], one characteristic of literacy as social practice is that there is a different kind of literacy for different settings. Academic literacy is a kind of literacy that is practiced and developed in an academic setting for academic purposes. Lea and Street [4] developed an academic literacies approach with the framework of New Literacy Studies, and consider the importance of social cultural contexts in shaping reading and writing practices, including learning processes in academic contexts.

A number of studies have been carried out concerning the culture of academia. Lea and Street [4] investigated the contradiction in the interpretation of student writing between undergraduate students and instructors in two universities in England. Meanwhile, Nambia [5] reveals that students tend to read at surface level and are not yet able to use critical and analytical thinking to process information they gain. Cox [6] looks into academic literacies as a particular discourse that requires those participating in the practices to be familiar with academic ways of reading and writing. Cox highlights a common gap between professors' assumption of their students' academic ability and the realities that many postgraduate students are still not accustomed to academic discourses. This gap forces students with little or no familiarity with academic discourses to find their own ways to comprehend and write academic texts to succeed with little guidance [6]. At the level of postgraduate study, Butler [7] suggests that lecturers' awareness level of academic literacy brings a positive impact on the academic interaction between supervisors and their students. 


\section{METHOD}

In line with the perspective of New Literacy Studies, this study employed a descriptive qualitative approach. The data were collected by using a survey that involved 33 postgraduate students in the English Education study program at Universitas Negeri Surabaya. The respondents were asked to fill out an academic literacy questionnaire that comprises 14 aspects of academic literacy practices. Each aspect contains 916 questions. Several questions asked the respondents to state the frequency of carrying out academic literacy practices. Some other questions required that the respondents measure themselves in terms of their perception of their academic literacy competences. To ensure consistency, brief open-ended interviews were also conducted to ask how the respondents perceived their academic literacy practices. The data collected from the questionnaire were compared to the ones gained from the interviews.

\section{RESULT AND DISCUSSION}

In an academic setting, writing is one of the most commonly given assignments. Students are given writing assignment to help them understand the assigned readings critically and to encourage independent thinking. Responses given by the respondents in this study indicate a variety of writing assignments, ranging from academic to reflective writing. Five most common writing assignments were argumentative essays (33\% respondents), summarizing (27\%), analytical essays (24\%) and evaluative ones (24\%). All these assignments require analysis, synthesis, critical thinking, and research. These findings suggest that lectures in the English Education Postgraduate Program of Unesa set relatively high expectations of students' writing competence. Those who are not familiar with documentation styles to avoid plagiarism may experience difficulties in their study.

Based on the data collected, students of English Education postgraduate program believed that their academic writing competence is still not adequate to help them succeed in their study. Only $6 \%$ of the 33 respondents saw themselves excel academically, and $23 \%$ perceived that they had good competence. This means that more than two third of the respondents are on the side that see themselves insufficient in academic writing.

Further investigation of the data reveals interesting findings. There are four aspects of academic writing competence in which the respondents felt that they were not adequate. The aspects were quoting and referencing to avoid plagiarism, using appropriate documentation styles that suit their discipline, transforming nonverbal to verbal information, and contributing substantially in online discussions. These findings imply that most postgraduate students under study were not prepared to enter the academic world that apparently sets a high demand concerning academic honesty and plagiarism. Furthermore, students' lack of ability to contribute in online discussions can be interpreted as a problem in expressing their thoughts critically. This may be influenced by a cultural factor in Indonesia, in which expressing opinions (especially the dissenting ones) may be considered impolite and thus not culturally acceptable.

In the academic context, research has become technologybased, in which resources are limitless. The results of this study indicate ample use of technology in the learning process. Students are expected to use word-processing software to manage and produce texts, to navigate emails to manage information, to understand online communication ethics, and more importantly, to apply the skills of managing and documenting references, which is a very important skill in the academic setting.

\section{CONCLUSION}

The result of the study indicates the complexities of academic literacy in postgraduate level. Based on the students' perception, reading and writing assignments given to them varied, ranging from academic reading and writing to reflective ones. Similarly, the use of technology has already been incorporated in learning process for different purposes, i.e. to gain information and to produce and communicate their ideas, both offline and online. On the other hand, postgraduate students in this study perceived that their academic writing ability in various forms of writing is still not adequate. This implies a gap between expectations and realities in the practices of academic literacy among students under study. The findings suggest that the selection process in postgraduate program at Universitas Negeri Surabaya be carried out more tightly to gain potential students who already possess a sufficient level of academic literacy. Moreover, the learning process in the postgraduate program should also provide more mentoring to develop various practices of academic literacy in the classroom.

\section{REFERENCES}

[1] E. W. Hirst, "Engaging heterogeneity: Tertiary literacy in new times.", Retrieved June 28, 2007, from http://www.aare.edu.au/02pap/hir02208.htm, 2002.

[2] M. Shih, "Beyond comprehension exercises in the ESL academic reading class", TESOL Quarterly vol. 26, no. 2, pp. 289-317, 1992.

[3] D. Barton, M. Hamilton, and R. Ivanic, Situated Literacies: Reading and Writing in Context. London: Rutledge, 2000

[4] M. R. Lea, B. V. Street, "Student Writing in Higher Education: An Academic Literacies Approach. Studies in Higher Education vol. 23, no.2, pp. 157-172, 1998

[5] R. M. B. Nambia, "Enhancing Academic Literacy among Tertiary Learners: A Malaysian Experience." 3 L Journal of Language Teaching, Linguistics and Literature vol. 13, pp. 10-22, 2007.

[6] R. D. Cox, The College Fear Factor. Boston: Harvard UP, 2009.

[7] G. Butler, "Supervisor perception of Academic literacy requirements of postgraduate students at the University of Pretoria", Journal of Language Teaching vol. 45, no. 1, pp. 7-22, 2011. 